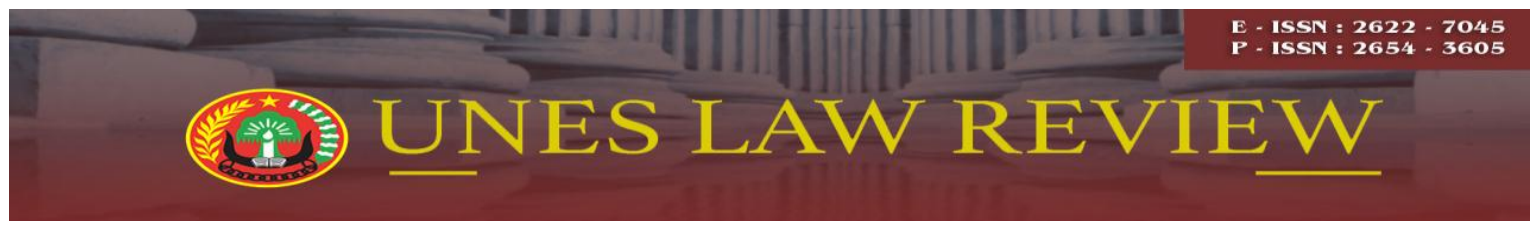

Email: uneslawreview@gmail.com

Online: http://review-unes.com/index.php/law

Volume 2, Issue 4, Juni 2020

\title{
PENERAPAN UNSUR TINDAK PIDANA PENCUCIAN UANG YANG BERASAL DARI HASIL TINDAK PIDANA NARKOTIKA PADA TINGKAT PENYIDIKAN (Studi Pada BNNP dan Ditresnarkoba Polda Sumbar)
}

\author{
Kusnedi \\ Polres Kota Padang, Padang, Indonesia \\ Email: kusnedi20@gmail.com
}

\begin{abstract}
The crime of money laundering does not stand alone because the assets placed by integration are obtained from a crime. The investigator has the authority to submit an application to the District Court so that the court decides assets that are known or reasonably suspected to be the result of narcotics crime being assets of the State or returned to those entitled under Article 137 letter (a) of Law Number 35 Year 2009 regarding Narcotics, Article 3, 4, and 5 paragraph (1) of Law Number 8 of 2010 concerning the prevention and eradication of criminal acts of laundering. This has an impact on pinyidik at BNNP and the Directorate the West Sumatra Regional Police in proving the element of money laundering which is allegedly the result of narcotics crime. Application of elements of laundering money derived from proceeds of crime, narcotics based on Article 137 (a) Law of the Republic of Indonesia Number 35 Year 2009 on Narcotics, Articles 3, 4, and 5, paragraph (1) of the Act Republic of Indonesia Number 8 Year 2010. Constraints are faced by investigators BNNP namely: a) Constraints internal factors, and $b$ ) constraint factors external. Efforts were made to overcome the obstacles by the investigation BNNP, namely: a) attempts to overcome internal factor constraints faced by investigators BNNP in combating money laundering based narcotic crime, and $b$ ) the efforts made to overcome external factor constraints by BNNP investigators in eradicating money laundering which is based on narcotics crime.
\end{abstract}

Kata Kunci: Penyidik, Narkotika, Tindak Pidana Narkotika, Ditresnarkoba, Tindak Pidana Pencucian Uang, BNNP

\section{PENDAHULUAN}

Tindak Pidana Pencucian uang sebagai suatu kejahatan mempunyai ciri khas yaitu bahwa kejahatan ini bukan merupakan kejahatan tunggal tetapi kejahatan ganda. Tindak pidana pencucian uang tidak berdiri sendiri karena harta kekayaan yang ditempatkan, ditransfer, atau dialihkan dengan cara integrasi itu diperoleh dari tindak pidana, berarti sudah ada tindak pidana lain yang mendahuluinya (predicate crime) (Adrian Sutedi, 2008:182). Pelaku tindak pidana pada umumnya berusaha menyembunyikan atau menyamarkan asal usul harta kekayaan yang merupakan hasil dari tindak pidana dengan 
berbagai cara agar harta kekayaan hasil kejahatannya sulit ditelusuri oleh aparat penegak hukum sehingga dengan leluasa memanfaatkan harta kekayaan tersebut baik untuk kegiatan yang sah maupun dengan kegiatan yang tidak sah. Kualifikasi tindak pidana pencucian uang dirumuskan sebagai penempatan harta kekayaan yang diketahuinya atau patut diduganya merupakan hasil tindak pidana ke dalam penyedia jasa keuangan, baik atas nama sendiri atau atas nama orang lain.

Ketentuan Pasal 67 Undang-Undang Nomor 8 Tahun 2010 tentang Tindak Pidana Pencucian Uang atau disebut selanjutnya UU TPPU memberikan kewenangan kepada penyidik untuk mengajukan permohonan kepada Pengadilan Negeri agar pengadilan memutuskan harta kekayaan (asset) yang diketahui atau patut diduga merupakan hasil tindak pidana menjadi asset Negara atau dikembalikan kepada yang berhak (Muhammad Yusuf, 2013:167). Salah satu yang menjadi perhatian saat ini dalam menjalankan tindak pidana pencucian uang tersebut yang paling banyak merugikan adalah peredaran narkotika ditengah-tengah masyarakat.

Money laundering adalah bentuk baru dari kejahatan yang terorganisir yang berkaitan erat dengan kejahatan narkoba, pelacuran, penyeludupan, dan kejahatan lainnya. Kejahatan Money laundering merupakan kejahatan yang sangat banyak merugikan Negara. Seseorang diketahui melakukan Tindak Pidana Pencucian Uang tersebut, maka sebagaimana terdapat didalam Pasal 6 ayat (1) Undang-undang Nomor 15 Tahun 2002 tentang Tindak Pidana Pencucian Uang adalah Setiap orang yang menerima atau menguasai: Harta Kekayaan yang diketahuinya atau patut diduganya merupakan hasil tindak pidana, dipidana dengan pidana penjara paling singkat 5 (lima) tahun dan paling lama 15 (lima belas) tahun dan denda paling sedikit Rp 5.000.000.000,00 (lima milyar rupiah) dan paling banyak Rp 15.000.000.000,00 (lima belas milyar rupiah).

Berbagai upaya yang telah dilakukan pemerintah Indonesia dalam memberantas peredaran narkotika, terutama dalam tindak pidana pencucian uang. Namun upaya tersebut ada yang berhasil namun ada yang gagal, dapat dilihat karena perkembangan jaman saat ini terutama dalam bidang teknologi sehingga membuat para Bandar narkotika dapat menyembunyikan tempat persembunyian uang bahkan sampai hasil benda yang mereka peroleh dari menjual barang haram tersebut. 
Penyalahgunaan narkotika adalah salah satu bentuk perilaku yang menyimpang. Efek dari penggunaan narkotika itu sangat banyak salah satunya adalah memberikan efek Depresant yaitu mengendurkan atau mengurangi aktivitas atau kegiatan susunan syaraf pusat, sehingga dipergunakan untuk menenangkan syaraf seseorang untuk dapat tidur/istirahat (AR.Sujono dan Bony Daniel, 2011:6). Bahaya narkotika saat ini sangat mengancam bagi masyarakat kita khususnya Indonesia dan sangat berdampak luas korbannya saat ini adalah kaum muda Indonesia.

Pengertian narkotika menurut Pasal 1 ayat (1) Undang-undang Nomor 35 tahun 2009 tentang Narkotika adalah:

"Zat atau obat yang berasal dari tanaman atau bukan tanaman, baik sintesis maupun semi sintesis, yang dapat menyebabkan penurunan atau perubahan kesadaran, hilangnya rasa, mengurangi sampai menghilangkan rasa nyeri,dan dapat menimbulkan ketergantungan, yang dibedakan kedalam golongan-golongan sebgaimana terlampir dalam Undang-undang”.

Melindungi masyarakat dari bahaya penyalahgunaan narkotika dan mencegah serta memberantas peredaran gelap narkotika, dalam Undang-undang ini diatur juga mengenai prekusor narkotika karena prekursor narkotika merupakan zat atau bahan pemula atau bahan kimia yang dapat digunakan dalam pembuatan narkotika.

Undang-Undang Nomor 5 tahun 1997 maupun Undang-Undang 22 tahun 1997, apabila dikaji secara mendalam, didalamnya telah banyak tertuang dengan tegas dan jelas keinginan pemerintah dalam memberantas secara tuntas peredaran dan penggunaan narkotika yang tidak sesuai dengan standar medis. Tindak pidana sebelumnya telah dikategorikan sebagai unordinary crime (kejahatan luar biasa), untuk membantu penegak hukum yang telah ada seperti Kepolisian dan Kejaksaan dalam pemberantasan narkotika. Lembaga yang sebagaimana dimaksud adalah Badan Narkotika Nasional (BNN) yang merupakan salah satu lembaga nonstruktural yang berkedudukan dibawah dan bertanggung jawab langsung terhadap Presiden Republik Indonesia. Badan Narkotika Nasional tersebut bertugas untuk mengkoordinasi instansi pemerintah terkait dalam penyusunan kebijakan dan pelaksaannya dibidang ketersediaan, pencegahan, pemberantasan penyalahgunaan dan peredaran gelap narkotika yang sering terjadi pada saat ini. Melaksanakan tugasnya, sesuai dengan Pasal 4 Peraturan Presiden Nomor 23 Tahun 2010, Badan Narkotika Nasional 
(BNN) berwenang dalam melakukan penyidikan dan penyelidikan penyalagunaan dan peredaran gelap narkotika dan prekursor narkotika.

Berkaitan dengan hal tersebut diantara penerapan usur hukum yang juga mempunyai kewenagan dan peran penting terhadap kasus tindak pidana pencucian uang oleh Bandar Narkotika ialah Lembaga Negara Badan Narkotika Nasional (BNN). Penyidik dalam hal ini yaitu Badan Narkotika Nasional Provinsi (BNNP), diharapkan mampu membantu proses pengungkapan terhadap kasus tindak pidana pencucian uang oleh Bandar Narkotika tersebut, serta BNNP Sumatera Barat tersebut harus mampu membuat strategi dalam upaya menindak tegas para pelaku kejahatan pencucian uang oleh para Bandar Narkotika.

Latar belakang perbuatan pelaku peredaran gelap Narkotika yang mengalihkan dan menyembunyikan harta kekayaan hasil kejahatan melaui sistem keuangan adalah memindahkan atau menjauhkan pelaku dari kejahatan yang menghasilkan proceeds of crime dari kejahatan yang dilakukan, memisahkan proceeds of crime dari kejahatan yang dilakukan, menikmati hasil kejahatan tanpa adanya kecurigaan kepada pelaku, serta melakukan reinvestasi hasil kejahatan untuk aksi kejahatan selanjutnya atau ke dalam bisnis yang sah. Penanggulangan kejahatan peredaran gelap Narkotika dengan memisahkan proceeds crime dari kejahatan yang dilakukan dan penikmatan hasil kejahatan berupa penempatan tindak pidana Narkotika sebagai core crime (Bismar Nasution, 2007:219).

Di Provinsi Sumatera Barat berdasarkan data yang penulis peroleh dari Lembaga Pemasyarakatan Klas II A Padang, pada tahun 2017 jumlah narapidana dan tahanan sebanyak 980 orang, narapidana dan tahanan kasus narkotika berjumlah 685 orang di mana dari jumlah tersebut terdapat 29 orang merupakan residivis tindak pidana narkotika. Direktorat Reserse Narkoba Kepolisian Daerah Sumatera Barat menguraikan bahwa terhitung sejak bulan Januari hingga Maret 2018 terdapat 280 kasus dengan jumlah tersangka 387 orang, pada tahun 2017 terdapat sebanyak 460 kasus dengan tersangka sebanyak 593 orang, dan pada tahun 2016 terdapat 824 kasus dengan jumlah tersangka mencapai 1.110 orang. serta tindak pidana pencucian uang yang berasal dari tindak pidana narkotika di Ditresnarkoba Polda Sumbar berjumlah 1 kasus dengan jumlah 2 tersangka tertangkap dan 2 orang DPO. 


\section{METODE PENELITIAN}

Spesifikasi penelitin yang digunakan dalam penelitian ini adalah penelitian hukum yuridis normatif dan yuridis empiris (terapan). Penelitian hukum normatif-empiris (terapan) selalu terdapat 2 (dua) tahap kajian. Tahap pertama, kajian mengenai hukum normatif (perundang-undangan, peraturan menteri, dan buku) yang berlaku dan tahap kedua kajian hukum empiris berupa penerapan (implementasi) pada peristiwa hukum in concreto guna mencapai tujuan yang telah ditentukan (Abdulkadir Muhammad, 2004:53).

Proses pengumpulan dan penyajian sehubungan dengan penelitian ini maka digunakan metode pendekatan secara yuridis normatif dan yuridis empiris. Pendekatan yuridis normatif adalah suatu pendekatan yang dilakukan dimana pengumpulan dan penyajian data dilakukan dengan mempelajari dan menelaah konsep-konsep dan teori-teori serta peraturan-peraturan secara kepustakaan yang berkaitan dengan penerapan unsur tindak pidana perakara Narkotika sebagai tindak pidana asal dalam tindak pidana pencucian uang. Sedangkan pendekatan yuridis empiris yaitu dengan melakukan pengkajian dan pengolahan terhadap data primer sebagai data utama yaitu fakta-fakta dan perilaku empiris dalam praktik penerapan unsur hukum pidana perkara Narkotika sebagai tindak pidana asal dalam tindak pidana pencucian uang (Soerjono Soekanto, 1986:91).

\section{HASIL PENELITIAN DAN PEMBAHASAN}

\section{Penerapan Unsur Tindak Pidana Pencucian Uang Yang Berasal Dari Hasil Tindak Pidana Narkotika Pada Tingkat Penyidikan Oleh BNNP dan Ditresnarkoba Polda Sumatera Barat}

Analisis penulis terhadap tersangka Ferizal alias Feri alias Gaek yang dinyatakan bersalah berdasarkan unsur-unsur yang pada Pasal 3, Pasal 4, Pasal 5 ayat (1) Undangundang Republik Indonesia Nomor 8 Tahun 2010 tentang pencegahan dan pemberantasan Tindak Pidana Pencucian Uang dan Pasal 137 huruf a Undang-undang Republik Indonesia Nomor 35 Tahun 2009 tentang Narkotika

Unsur-unsur yang terpenuhi pada Tindak pidana pencucian uang berdasarkan Pasal 3, Pasal 4, Pasal 5 ayat (1) Undang-undang Republik Indonesia Nomor 8 Tahun 2010 tentang pencegahan dan pemberantasan Tindak Pidana Pencucian Uang antara lain:

1. Unsur setiap orang 
Adapun orang yang memenuhi unsur tersebut adalah saudara Ferizal alias Feri alias Gaek.

2. Unsur menempatkan

Unsur ini terpenuhi berdasarkan fakta tersangka telah menerima uang yang diduga hasil transaksi narkotika dari Neneng Sasmita, Rima Anatasia dan Syafitria, dengan cara transfer uang lewat rekening BRI.

3. Unsur mentransfer

Unsur ini terpenuhi berdasarkan fakta tersangka telah menerima uang yang diduga hasil transaksi narkotika dari Syafitria, dengan cara transfer uang lewat rekening BRI.

4. Unsur membelanjakan

Unsur ini terpenuhi dalam bentuk pembelian mobil dan pembangunan rumah.

5. Unsur membayarkan

Unsur ini terpenuhi berdasarkan pembayaran untuk pembelian mobil dan pembelian rumah.

6. Unsur menyembunyikan atau menyamarkan asal usul sumber rumah.

Unsur ini terpenuhi menyamarkan asal usul sumber dalam bentuk mobil dan

7. Unsur peruntukan, lokasi, pengalihan hak, atau kepemilikan yang sebenarnya atas harta kekayaan

Unsur ini terpenuhi kepemilikan yang sebenarnya atas harta kekayaan berupa mobil dan rumah.

8. Unsur menggunakan harta kekayaan yang diketahuinya atau patut diduganya merupakan hasil tindak pidana

Unsur ini terpenuhi harta kekayaan yang digunakan berupa mobil dan rumah.

Adapun beberapa unsur yang tidak terpenuhi pada Pasal 3, Pasal 4, Pasal 5 ayat (1) Undang-undang Republik Indonesia Nomor 8 Tahun 2010 tentang pencegahan dan pemberantasan Tindak Pidana Pencucian Uang antara lain:

1. Unsur mengalihkan

2. Unsur menghibahkan

3. Unsur menerima atau menguasai penempatan

4. Unsur hibah atau sumbangan

5. Unsur penitipan atau penukaran

6. Unsur penitipan

7. Unsur membawa keluar negeri

8. Unsur mengubah bentuk, menukarkan dengan mata uang atau surat berharga atau perbuatan lain atas harta kekayaan yang diketahuinya atau patut diduganya merupakan hasil kejahatan.

Berdasarkan unsur-unsur yang terpenuhi cukup untuk menerapkan pidana Pasal 3,

Pasal 4, Pasal 5 ayat (1) Undang-undang Republik Indonesia Nomor 8 Tahun 2010 tentang pencegahan dan pemberantasan Tindak Pidana Pencucian Uang terhadap tersangka Ferizal alias Feri alias Gaek meski ada beberapa unsur yang tidak terpenuhi. 
Adapun asal dari unsur tindak pidana pencucin uang adalah hasil dari tindak pidana narkotika, unsur dari tindak pidana narkotika tersangka Ferizal alias Feri alias Gaek berdasarkan Pasal 137 huruf a Undang-undang Republik Indonesia Nomor 35 Tahun 2009 tentang Narkotika dengan unusr antara lain:

1. Unsur setiap orang

Adapun orang yang memenuhi unsur tersebut adalah saudara Ferizal alias Feri alias Gaek.

2. Unsur menempatkan

Unsur ini terpenuhi dengan berdasarkan fakta menerima uang yang diduga hasil transaksi narkotika di rekening Bank BRI

3. Unsur membayarkan atau membelanjakan

Unsur ini terpenuhi dengan berdasarkan fakta pembelian mobil dan rumah beserta tanah beserta fakta pembayaran dan penerimaan transfer transaksi narkotika.

4. Unsur menyembunyikan atau menyamarkan

Unsur ini terpenuhi dengan berdasarkan fakta-fakta temuan keuntungan transaksi narkotika yang diperoleh tersangka berupa mobil dan rumah.

Adapun beberapa unsur yang tidak terpenuhi pada Pasal 137 huruf a Undangundang Republik Indonesia Nomor 35 Tahun 2009 tentang Narkotika antara lain:

1. Unsur menginvestasikan

2. Unsur menyimpan

3. Unsur menghibahkan, mewariskan

4. Unsur mentransfer uang, harta, benda atau aset baik dalam bentuk benda bergerak atau tidak bergerak, berwujud atau tidak berwujud yang diketahuinya berasal dari tindak pidana narkotika dan/atau tindak pidana prekursor narkotika.

Berdasarkan unsur-unsur yang terpenuhi cukup untuk menerapkan pidana Pasal 137 huruf a Undang-undang Republik Indonesia Nomor 35 Tahun 2009 tentang Narkotika terhadap tersangka Ferizal alias Feri alias Gaek meski ada beberapa unsur yang tidak terpenuhi.

Sehingga dapat di analisis berdasarkan penerapan unsur-unsur di atas bahwa tersangka Ferizal alias Feri alias Gaek melakukan tindak pidana pencucian uang yang berasal dari tindak pidana narkotika sesuai dengan Pasal 3, Pasal 4, Pasal 5 ayat (1) Undang-undang Republik Indonesia Nomor 8 Tahun 2010 tentang pencegahan dan pemberantasan Tindak Pidana Pencucian Uang dan Pasal 137 huruf a Undang-undang Republik Indonesia Nomor 35 Tahun 2009 tentang Narkotika. 


\section{Kendala Yang Dihadapi Oleh BNNP Dalam Penerapan Unsur Tindak Pidana Pencucian Uang Yang Berasal Dari Hasil Tindak Pidana Narkotika Pada Tingkat Penyidikan}

Berdasarkan hasil wawancara dengan Brigadir Tomi Zaini selaku penyidik pembantu di BNNP Sumatera Barat menjelaskan kendala yang dialami saat melakukan penyidikan dalam kasus ini antara lain adalah:

1. Faktor Internal

Kendala utama yang dihadapi oleh BNNP sendiri ialah lambatnya koordinasi yang dilakukan dengan BNN RI. Seperti diketahui sebelumnya bahwa untuk mendapatkan data mutasi bank dan melakukan pemblokiran rekening bank, BNNP harus terlebih dahulu mengajukan surat permohonan permintaan data mutasi bank dan surat permohonan permintaan pemblokiran atas nama tersangka beserta dengan Laporan Pengajuan Perkara yang berisi resume berkas perkara kepada BNN RI. Mengingat pentingnya data mutasi bank sebagai barang bukti utama, maka sangat diperlukan adanya kecepatan dalam melakukan koordinasi karena dikhawatirkan uang pelaku dapat beralih dan berpindah tangan sehingga penyidik akan kesulitan dalam melacak uang tersebut terlebih lagi jika terhadap rekening bank milik pelaku belum dilakukan pemblokiran maka tidak akan menutup kemungkinan semua sisa saldo tabungan akan diambil.

2. Faktor Eksternal

Kendala yang dihadapi adalah lamanya proses permintaan data mutasi bank oleh pihak bank terkait. Hal ini tentunya dapat menghambat proses penyidikan yang seharusnya berjalan secara cepat. Sedangkan kendala yang terakhir yakni, akses jarak tempuh yang cukup jauh dan memakan banyak biaya untuk BNNP melakukan koordinasi dengan PPATK.

Tentunya kendala yang di hadapi BNNP tersebut tidak sesuai dengan salah satu asas hukum acara pidana yaitu asas sederhana, cepat dan biaya ringan dalam melakukan penyidikan tentunya dibutuhkan kecepatan dan ketepatan waktu karena menyangkut Hak Asasi Manusia yakni penahanan tersangka. Dengan adanya batasan waktu penahanan terhadap tersangka sebagaimana diatur dalam KUHAP (KITAB Undang-undang Hukum Acara Pidana) maupun Undang-undang Republik Indonesia Nomor 35 Tahun 2009 tentang Narkotika, maka proses penyidikan pun harus dapat diselesaikan secara tepat waktu.

\section{Upaya yang dilakukan dalam mengatasi kendala penyidikan BNNP}

Berdasarkan hasil wawancara dengan Brigadir Tomi Zaini selaku penyidik pembantu di BNNP Sumatera Barat menjelaskan upaya yang dilakukan untuk mengatasi kendala yang dialami saat melakukan penyidikan dalam kasus ini antara lain adalah:

1. Faktor Internal

Upaya yang dilakukan untuk mengatasi lamanya proses untuk permintaan data mutasi bank dan melakukan pemblokiran terhadap rekening bank terdakwa, BNNP 
mengupayakan dengan komunikasi yang cukup baik menggunakan media elektronik dengan BNN Pusat bagian Pengawasan Barang Bukti dan Aset yang memberikan persetujuan dan memberikan surat izin kepada BNNP untuk mengajukan data mutasi bank dan pemblokiran rekening kepada bank terkait. Pada mulanya penyidik BNNP mengirim Laporan Pengajuan Pekara kepada BNN Pusat melalui electronic mail (email) dan segera menghubungi pihak Pengawasan Barang Bukti untuk membaca menganalisis kiriman Laporan Pengajuan Perkara tersebut untuk segera dapat ditindak lanjuti.

\section{Faktor Eksternal}

Untuk mengatasi kendala mutasi yang terlalu lama, pihak BNN RI secara intensif melakukan upaya koordinasi dengan pihak bank untuk segera mengeluarkan (print out) semua data mutasi yang dimintakan guna penyidikan lebih lanjut dan upaya dalam mengatasi jarak yang terlalu jauh untuk melakukan koordinasi antara BNNP dengan PPATK yaitu, perwakilan penyidik BNNP diberangkatkan ke Jakarta dengan anggaran yang sudah disesuaikan dengan anggaran penyidikan yang diberikan BNN RI.

Upaya yang diterapkan tersebut diharapkan dapat mengatasi kendala-kendala dalam proses penyidikan sehingga tidak memakan waktu yang lama dan biaya yang ringan, untuk mewujudkan asas hukum acara pidana yaitu asas sederhana, cepat dan biaya ringan.

\section{PENUTUP}

\section{Kesimpulan}

Berdasarkan hasil penelitian, pembahasan dan analisis yang telah diuraikan pada bab sebelunya, maka disimpulkan sebagai berikut:

1. Ada beberapa penerapan unsur tindak pidana pencucian uang yang berasal dari hasil tindak pidana narkotika berdasarkan pada Pasal 137 huruf (a) Undang-undang Republik Indonesia Nomor 35 Tahun 2009 tentang Narkotika, Pasal 3, 4, dan 5 ayat (1) Undang-undang Republik Indonesia Nomor 8 Tahun 2010 tentang pencegahan dan pemberantasan tindak pidana pencucian uang, unsur yang terpenuhi antara lain adalah 1) Unsur setiap orang yaitu saudara Ferizal alias Feri alias Gaek, 2) Unsur menempatkan yaitu menerima uang yang diduga hasil transaksi narkotika dari Neneng Sasmita, Rima Anatasia dan Syafitria, dengan cara transfer uang lewat rekening BRI, 3) Unsur mentransfer yaitu tersangka telah menerima uang yang diduga hasil transaksi narkotika dari Syafitria, dengan cara transfer uang lewat rekening BRI, 4) Unsur membelanjakan yaitu pembelian mobil dan pembangunan rumah, 5) Unsur membayarkan yaitu pembayaran untuk pembelian mobil dan pembelian rumah, 6) Unsur menyamarkan asal usul sumber yaitu menyamarkan asal usul sumber dalam bentuk mobil dan rumah, 7) Unsur kepemilikan yang sebenarnya atas harta kekayaan yaitu berupa mobil dan rumah dan 8) Unsur menggunakan harta kekayaan yang diketahuinya atau patut diduganya merupakan hasil tindak pidana yaitu berupa mobil dan rumah. 
2. Kendala yang dihadapi oleh penyidik BNNP dalam menanggulanggi penerapan unsur tindak pidana pencucian uang yang berasal dari hasil tindak pidana narkotika pada tingkat penyidikan di bagi menjadi dua kendala yaitu:

a. Kendala faktor internal yang dihadapi oleh penyidik BNNP dalam memberantas tindak pidana pencucian uang yang didasarkan tindak pidana narkotika, yakini lambatnya koordinasi yang dilakukan dengan BNN RI. Banyaknya prosedur yang dilalui sehingga dapat menghambat kecepatan dalam pemblokiran rekening atas nama tersangka.

b. Kendala faktor eksternal oleh penyidik BNNP dalam memberantas tindak pidana pencucian uang yang didasarkan tindak pidana narkotika, yakni lamanya proses permintaan data mutasi bank oleh pihak bank terkait dan akses jarak tempuh yang cukup jauh sehingga memakan banyak biaya untuk BNNP melakukan koordinasi dengan PPATK.

3. Upaya yang dilakukan dalam mengatasi kendala penyidikan BNNP, yaitu:

a. Upaya untuk mengatasi kendala faktor internal yang dihadapi oleh penyidik BNNP dalam memberantas tindak pidana pencucian uang yang didasarkan tindak pidana narkotika, yakni dilakukan oleh penyidik BNNP menjaga komunikasi yang cukup baik menggunakan media elektronik dengan BNN RI bagian pengawasan barang bukti dan aset.

b. Upaya yang dilakukan dalam mengatasi kendala faktor eksternal oleh penyidik BNNP dalam memberantas tindak pidana pencucian uang yang didasarkan tindak pidana narkotika, yakni BNNP melakukan koordinasi dengan BNN RI untuk memintak kepada bank untuk sesegera mungkin mengeluarkan print out mutasi buku rekening tersangka dan BNNP menggunakan biaya yang telah dianggarkan oleh BNN RI untuk berangkat ke jakarta dalam melakukan koordinasi dengan PPATK.

\section{Saran}

Ada beberapa saran yang ingin disampaikan terkait dengan penerapan unsur tindak pidana pencucian uang dari hasil tindak pidana narkotika pada tingkat penyidikan oleh BNNP dan Ditresnarkoba Polda Sumatera Barat, antara lain:

1. Hendaknya BNNP dan kepolisian mengoptimalkan amanat peraturan perundangundangan sebagai salah satu penyidik tindak pidana pencucian uang yang disebabkan tindak pidana narkotika sehingga tindak pidana tersebut dapat terungkap yang berarti akan semakin mempertegas posisi Undang-Undang No. 8 Tahun 2010 Tentang Pencegahan Dan Pemberantasan Tindak Pidana Pencucian Uang bernilai kepastian hukum.

2. Hendaknya dalam peran yang dimiliki oleh BNNP dan Polda Sumatera Barat dalam pemberantasan tindak pidana narkotika yang berhubungan dengan tindak pidana pencucian uang juga dicantumkan dalam bentuk regulasi baik bersifat internal maupun eksternal agar semakin mempertegas posisi BNNP dan Polda Sumatera Barat secara khusus atau secara umum Kepolisian Republik Indonesia sebagai salah satu penegak 
hukum yang mempunyai kewenangan dalam melakukan penyidikan tindak pidana tersebut.

3. Hendaknya untuk mengatasi kendala yang dialami BNNP dan Polda Sumatera Barat dalam pemberantasan tindak pidana narkotika yang berhubungan dengan tindak pidana pencucian uang agar pemerintah membantu perealisasiannya.

\section{DAFTAR PUSTAKA}

\section{Buku Teks:}

Abdulkadir Muhammad, Hukum dan Penelitian Hukum, Citra Aditya Bakti, Bandung, 2004 ,

Adrian Sutedi, Tindak Pidana Pencucian Uang, Citra Aditya Bakti, Bandung, 2008,

AR.Sujono dan Bony Daniel, Komentar dan Pembahasan Undang-Undang Nomor 35 Tahun 2009 tentang Narkotika,Sinar Grafika, Jakarta, 2011,

Bismar Nasution, Hukum Kegiatan Ekonomi I, Books Terrace \& Library, Bandung, 2007,

Muhammad Yusuf, Merampas Aset Koruptor, Penerbit Buku Kompas, Jakarta, 2013,

Soerjono Soekanto, Pengantar Penelitian Hukum, UI Press, Jakarta, 1986,

\section{Peraturan Undang-Undang :}

Undang-Undang Dasar Negara Republik Indonesia Tahun 1945.

Undang-Undang Nomor 1 Tahun 1946 tentang Peraturan Hukum Pidana.

Undang-Undang Nomor 8 Tahun 1981 tentang Hukum Acara Pidana (KUHAP).

Undang-undang Nomor 8 Tahun 2010 tentang Pencegahan dan Pemberantasan Tindak Pidana Pencucian Uang.

Undang-Undang Nomor 35 Tahun 2009 tentang Narkotika.

Undang-Undang Republik Indonesia Nomor 5 Tahun 1983 tentang Zona Ekonomi Eksklusif Indonesia

Peraturan Pemerintah Nomor 27 tahun 1983 tentang Pedoman Pelaksanaan KUHAP

Peraturan Presiden Nomor 83 Tahun 2007 tentang Badan Narkotika Nasional

Peraturan Kepala Badan Narkotika Nasional Nomor 4 Tahun 2010 Jounto Peraturan Kepala Badan Narkotika Nasional Nomor 3 Tahun 2015 tentang Organisasi dan Tata Kerja Badan Narkotika Nasional Provinsi dan Badan Narkotika Nasional Kabupaten/ Kota

\section{Internet :}

https://sumbar.antaranews.com/berita/223457/polda-sumbar-ungkap-280-kasusnarko badari-januari-maret-2018. Diakses pada tanggal 2 mai 2019 pukul 04:58 WIB. 
https://www.covesia.com/archipelago/baca/40538/bnnp-pengguna-narkoba-di-sumbar meningkat-Tahun-2017. Diakses pada tanggal 2 mai 2019 pukul 05. 01 WIB.

https://www.google.co.id/amp/m.mediaindonesia.com/amp/amp_detail/117998peredar-annarkoba-meningkat-di-sumbar. Diakses pada tanggal 2 mai 2019 pukul 05.04 WIB. 